\title{
Calibrating the Leaf Colour Chart for Nitrogen Management in Maize (Zea mays L.) under Irrigated Condition
}

\author{
Shivakumar ${ }^{1}$, M.A. Basavanneppa ${ }^{2 *}$, B.G. Koppalkar ${ }^{1}$, \\ M.R. Umesh ${ }^{1}$ and Ashok Kumar Gaddi ${ }^{2}$ \\ ${ }^{1}$ Department of Agronomy, University of Agricultural Sciences, Raichur, Karnataka, India \\ ${ }^{2}$ Agricultural Research Station, Siruguppa- 583 121, Karnataka, India \\ *Corresponding author
}

\section{A B S T R A C T}

\begin{tabular}{|l|}
\hline K e y w or d s \\
$\begin{array}{l}\text { Grain yield, Nitrogen } \\
\text { management, Leaf } \\
\text { colour chart and } \\
\text { economics. }\end{array}$ \\
\hline Article Info \\
\hline $\begin{array}{l}\text { Accepted: } \\
\text { 10 September } 2017 \\
\text { Available Online: } \\
\text { 10 November 2017 }\end{array}$ \\
\hline
\end{tabular}

The field experimentwas conducted at Agricultural Research Station, Siruguppa, University of Agriculture Sciences, Raichur, Karnataka, during kharif 2016 to study the "Calibrating the leaf colour chart for maize (Zea mays L.) nitrogen management under irrigated condition" and to evaluate and establish LCC threshold values for saving fertilizer $\mathrm{N}$ and achieve higher grain yield. The experimental site was medium deep black soil. The experiment consists of ten treatments viz., $\mathrm{T}_{1}: \mathrm{N}$ application at $\mathrm{LCC}$ threshold $\leq$ $1, \mathrm{~T}_{2}$ : N application at LCC threshold $\leq 2, \mathrm{~T}_{3}: \mathrm{N}$ application at $\mathrm{LCC}$ threshold $\leq 3, \mathrm{~T}_{4}: \mathrm{N}$ application at LCC threshold $\leq 4, \mathrm{~T}_{5}: \mathrm{N}$ application at LCC threshold $\leq 4.5, \mathrm{~T}_{6}: \mathrm{N}$ application at LCC threshold $\leq 5, \mathrm{~T}_{7}: \mathrm{N}$ application at $\mathrm{LCC}$ threshold $\leq 5.5, \mathrm{~T}_{8}: \mathrm{N}$ application at $\mathrm{LCC}$ threshold $\leq 6, \mathrm{~T}_{9}: \mathrm{RDN}\left(190 \mathrm{~kg} \mathrm{ha}^{-1}\right)$ and $\mathrm{T}_{10}$ : Absolute control. These treatments were replicated thrice in Randomized Complete Block Design (RCBD). Application of nitrogen fertilizer based on LCC threshold $\leq 5$ recorded higher grain yield $\left(8339 \mathrm{~kg} \mathrm{ha}^{-1}\right)$, stover yield $\left(10424 \mathrm{~kg} \mathrm{ha}^{-1}\right)$ and harvest index (44.4\%). Net returns (Rs. 80650) and B:C ratio (2.88) were recorded in N application at LCC threshold $\leq 5$.

\section{Introduction}

Nutrient management has played a crucial role in achieving self-sufficiency in food grain production. The need for precise and responsive management of $\mathrm{N}$ fertilizer in Maize is compelling for both economic and environmental reasons. Static fertilizer recommendations based on average response lead to excessive fertilization in some years and inadequate fertilizers in years with high $\mathrm{N}$ losses. The uncertainty in optimum $\mathrm{N}$ rate poses risks for profit loses which is exacerbating by the asymmetric profit response of maize to $\mathrm{N}$ rates. The associated higher cost of under fertilization relative to over fertilization drives farmers to apply imbalanced rates. This uncertainty can be addressed by providing more accurate location and time specific recommendations that increase accuracy and reduce uncertainty.

The farmers generally use leaf colour as a visual and subjective indicator for $\mathrm{N}$ fertilizer need (Furuya, 1987). Since farmers generally prefer to keep leaves of the crop dark green, it leads to over application of fertilizers $\mathrm{N}$ resulting in low recovery efficiency. Thus, the spectral properties of leaves should be used in a more rational manner to guide need based 
fertilizer $\mathrm{N}$ applications. Further, in recent years many precision tools are being used in the nitrogen management especially in maize. Among these precision tools, leaf colour chart (LCC) is one and it was developed for rice and it is also suitable for maize as indicated by spectral reflectance measurement performance on rice (Balasubramanian et al., 1999 and Balasubramanian et al., 2002) and maize leaves (Witt et al., 2005). LCC helps in promoting need based variable $\mathrm{N}$ application to rice crop based on soil $\mathrm{N}$-supply and crop demand. It is an ideal tool to optimize $\mathrm{N}$ use, irrespective of the source of $\mathrm{N}$ applied (Balasubramanian, 1984 and Balasubramanian et al., 2000).

\section{Materials and Methods}

The field test turned into carried out at Agriculture Research Station, Siruguppa, University of Agriculture Sciences, Raichur and is located at $76^{\circ} 54^{\prime \prime}$ East longitude, $15^{\circ} 38^{\prime \prime}$ North Latitude and at an elevation of $380 \mathrm{~m}$ from MSL. The station is situated in Northern Dry zone (Region-II, Zone -3) of Karnataka. The experiment was laid out in Randomised Complete Block Design and soil was medium black and clay loam in texture, neutral in soil reaction (8.09) and low in electrical conductivity $\left(0.26 \mathrm{dSm}^{-1}\right)$.

The organic carbon content was 0.43 per cent and low in available $\mathrm{N}\left(225.80 \mathrm{~kg} \mathrm{ha}^{-1}\right)$, medium in available phosphorus $\left(24 \mathrm{~kg} \mathrm{P}_{2} \mathrm{O}_{5}\right.$ $\left.\mathrm{ha}^{-1}\right)$ and high in available potassium $(391 \mathrm{~kg}$ $\mathrm{K}_{2} \mathrm{O}$ ha $^{-1}$ ). The hybrid maize NK 6240 used in the investigation and seeds were dibbled at 60 $\mathrm{cm} \times 20 \mathrm{~cm}$ spacing. The $\mathrm{N}$ was managed through leaf colour chart thresholds. Irrespective of LCC levels, at basal $25 \mathrm{~kg} \mathrm{~N}$ full dose of $\mathrm{P}$ and $\mathrm{K}$ (75:37.5 $\mathrm{kg} \mathrm{P}_{2} \mathrm{O}_{5} \mathrm{~K}_{2} \mathrm{O}$ ha ${ }^{1}$ ) was applied to the soil in the form of single super phosphate and muriate of potash. For $\mathrm{T}_{1}, \mathrm{~T}_{2}, \mathrm{~T}_{3}, \mathrm{~T}_{4}, \mathrm{~T}_{5}, \mathrm{~T}_{6}, \mathrm{~T}_{7}$ and $\mathrm{T}_{8}$ followed intermittent $\mathrm{N}$ applications as guided by LCC threshold 1, 2, 3, 4, 4.5, 5, 5.5 and 6, respectively. The subsequent $\mathrm{N}$ applications were carried out by matching the colour of youngest fully expanded top leaf of ten randomly selected maize plants from each plot at 15 days interval, starting from 15 days after sowing of maize till initiation of silking. If the greenness of 6 or more out of ten leaves is less than LCC threshold, top-dressing 20 per cent recommended dose of nitrogen. Whereas the greenness of 5 or more out of ten leaves is more than LCC threshold, no $\mathrm{N}$ was applied. During analysis colour of the leaf with LCC under shade of the body was matched visually with LCC and disease/insect free leaves of normal crop. Matching of the leaf was discontinued and no further $\mathrm{N}$ was applied after initiation of silking. Total quantity of nitrogen applied was based on observing LCC values. In RDN treatment the 50 per cent $\mathrm{N}$ is applied as basal and remaining half dose of nitrogen in the form of urea was top dressed at 30 and 45 days after sowing (DAS) (Table 1). Immediately after sowing Atrazine 50 per cent WP @ $1.00 \mathrm{~kg}$ a.i ha ${ }^{-1}$ was sprayed to control weeds. At 20 days after sowing bicycle weeder was used and hand weeding was done at 35 and 50 days after sowing to manage weeds.

\section{Results and Discussion}

Among $\mathrm{N}$ application primarily based on leaf colour chart thresholds, drastically advanced maize grain yield turned into recorded with $\mathrm{N}$ application at LCC threshold $\leq 5\left(8339 \mathrm{~kg} \mathrm{ha}^{-}\right.$ ${ }^{1}$ ) and it was on par with $\mathrm{N}$ application at LCC threshold $\leq 5.5\left(7799 \mathrm{~kg} \mathrm{ha}^{-1}\right)$ and recommended nitrogen $\left(7756 \mathrm{~kg} \mathrm{ha}^{-1}\right)$ compared to rest of the treatments. Significantly lower maize grain yield was recorded under without fertilizer application $\left(3725 \mathrm{~kg} \mathrm{ha}^{-1}\right)$. Significantly higher amount of maize stover yield (10424 $\left.\mathrm{kg} \mathrm{ha}^{-1}\right)$ was registered under $\mathrm{N}$ application at LCC threshold $\leq 5$ and significantly lower was recorded under without fertilizer application (5264 kg ha ${ }^{-1}$ ) (Table 2). 
Table.1 Quantity of fertilizers applied for different treatments $\left(\mathrm{kg} \mathrm{ha}^{-1}\right)$ as influenced by leaf colour chart thresholds under irrigated condition

\begin{tabular}{|c|c|c|c|c|c|c|c|c|c|c|c|c|c|c|c|c|c|c|c|c|c|c|c|c|}
\hline \multirow{2}{*}{$\begin{array}{l}\text { Treat- } \\
\text { ments }\end{array}$} & \multicolumn{3}{|c|}{ Basal } & \multicolumn{3}{|c|}{15 DAS } & \multicolumn{3}{|c|}{30 DAS } & \multicolumn{3}{|c|}{45 DAS } & \multicolumn{3}{|c|}{60 DAS } & \multicolumn{3}{|c|}{75 DAS } & \multicolumn{3}{|c|}{ Total } & \multicolumn{3}{|c|}{$\begin{array}{c}\text { Saving of } \\
\text { fertilizers over } \\
\text { RDF }\end{array}$} \\
\hline & $\mathbf{N}$ & $\mathbf{P}$ & $\mathbf{K}$ & $\mathbf{N}$ & $\mathbf{P}$ & $\mathbf{K}$ & $\mathbf{N}$ & $\mathbf{P}$ & $\mathbf{K}$ & $\mathbf{N}$ & $\mathbf{P}$ & $\mathbf{K}$ & $\mathbf{N}$ & $\mathbf{P}$ & $\mathbf{K}$ & $\mathbf{N}$ & $\mathbf{P}$ & $\mathbf{K}$ & $\mathbf{N}$ & $\mathbf{P}$ & $\mathbf{K}$ & $\mathbf{N}$ & $\mathbf{P}$ & $\mathbf{K}$ \\
\hline $\mathbf{T}_{1}$ & 62 & 75 & 37.5 & - & - & - & - & - & - & - & - & - & - & - & - & - & - & - & 62 & 75 & 37.5 & 128 & 0 & 0 \\
\hline $\mathbf{T}_{2}$ & 62 & 75 & 37.5 & - & - & - & - & - & - & - & - & - & - & - & - & - & - & - & 62 & 75 & 37.5 & 128 & 0 & 0 \\
\hline $\mathbf{T}_{3}$ & 62 & 75 & 37.5 & - & - & - & - & - & - & - & - & - & - & - & - & - & - & - & 62 & 75 & 37.5 & 128 & 0 & 0 \\
\hline $\mathbf{T}_{4}$ & 62 & 75 & 37.5 & - & - & - & - & - & - & - & - & - & - & - & - & - & - & - & 62 & 75 & 37.5 & 128 & 0 & 0 \\
\hline $\mathbf{T}_{5}$ & 62 & 75 & 37.5 & 30 & - & - & - & - & - & - & - & - & - & - & - & - & - & - & 92 & 75 & 37.5 & 98 & 0 & 0 \\
\hline $\mathbf{T}_{6}$ & 62 & 75 & 37.5 & 30 & - & - & 30 & - & - & 30 & - & - & - & - & - & - & - & - & 152 & 75 & 37.5 & 38 & 0 & 0 \\
\hline $\mathbf{T}_{7}$ & 62 & 75 & 37.5 & 30 & - & - & 30 & - & - & 30 & - & - & 30 & - & - & - & - & - & 182 & 75 & 37.5 & 8 & 0 & 0 \\
\hline $\mathbf{T}_{8}$ & 62 & 75 & 37.5 & 30 & - & - & 30 & - & - & 30 & - & - & 30 & - & - & 30 & - & - & 212 & 75 & 37.5 & -22 & 0 & 0 \\
\hline $\mathbf{T}_{9}$ & 94 & 75 & 37.5 & 24 & - & - & 24 & - & - & 24 & - & - & 24 & - & - & - & - & - & 190 & 75 & 37.5 & 0 & 0 & 0 \\
\hline $\mathbf{T}_{10}$ & - & - & - & - & - & - & - & - & - & - & - & - & - & - & - & - & - & - & - & - & - & 0 & 0 & 0 \\
\hline $\begin{array}{l}\mathrm{T}_{1}: \\
\mathrm{T}_{4}:\end{array}$ & $\begin{array}{l}\text { app } \\
\text { app }\end{array}$ & $\begin{array}{l}\text { tior } \\
\text { tior }\end{array}$ & $\begin{array}{l}\mathrm{LCC} \\
\mathrm{LCC}\end{array}$ & $\begin{array}{l}\text { thre } \\
\text { thre }\end{array}$ & ld & & $\begin{array}{l}\mathrm{T}_{2}: \mathrm{N} \\
\mathrm{T}_{5}: \mathrm{N}\end{array}$ & $\begin{array}{l}\text { plic } \\
\text { plic }\end{array}$ & II & $\begin{array}{l}\mathrm{CC} \\
\mathrm{CC}\end{array}$ & sh & $\begin{array}{l}\leq 2 \\
\leq 4.5\end{array}$ & & & cati & at & th & hol & & & & & & \\
\hline $\begin{array}{l}\mathrm{T}_{7}: \\
\mathrm{T}_{10}\end{array}$ & $\begin{array}{l}\mathrm{J} \text { app } \\
\text { Abso }\end{array}$ & ation & $\begin{array}{l}\text { at } \mathrm{LCC} \\
\text { rol }\end{array}$ & thre & $d \leftrightharpoons$ & & $\mathrm{T}_{8}: \mathrm{N}$ & plic & on a & $\mathrm{CC}$ & esh & -6 & & & me & $n$ & 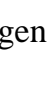 & 0 & $\mathrm{ha}^{-1}$ ) & & & & & \\
\hline
\end{tabular}


Table.2 Grain yield, stover yield and harvest index of maize as influenced by $\mathrm{N}$ application based on leaf colour chart thresholds under irrigated condition

\begin{tabular}{|c|c|c|c|c|c|c|}
\hline Treatments & \begin{tabular}{|c|}
$\begin{array}{c}\text { No. of grains } \\
\text { row }^{-1}\end{array}$ \\
\end{tabular} & \begin{tabular}{|c|} 
Cob weight \\
plant $^{-1}(\mathrm{~g})$
\end{tabular} & $\begin{array}{c}\text { Test weight } \\
\text { (g) }\end{array}$ & $\begin{array}{c}\text { Grain yield } \\
\left(\mathrm{kg} \mathrm{ha}^{-1}\right)\end{array}$ & $\begin{array}{c}\text { Stover yield } \\
\left(\mathrm{kg} \mathrm{ha}^{-1}\right)\end{array}$ & $\begin{array}{c}\text { Harvest } \\
\text { index }(\%)\end{array}$ \\
\hline T1: $\mathrm{N}$ application at LCC threshold $\leq 1$ & 26.9 & 181.0 & 31.7 & 5157 & 6652 & 43.7 \\
\hline T2: $\mathrm{N}$ application at LCC threshold $\leq 2$ & 29.1 & 182.2 & 32.7 & 6104 & 7835 & 43.8 \\
\hline T3: $\mathrm{N}$ application at LCC threshold $\leq 3$ & 29.9 & 183.0 & 32.9 & 6369 & 8191 & 43.7 \\
\hline T4: $\mathrm{N}$ application at LCC threshold $\leq 4$ & 30.2 & 183.1 & 33.1 & 7289 & 9184 & 44.2 \\
\hline T5: $\mathrm{N}$ application at LCC threshold $\leq 4.5$ & 30.4 & 187.0 & 33.6 & 7453 & 9316 & 44.4 \\
\hline T6: $\mathrm{N}$ application at LCC threshold $\leq 5$ & 33.1 & 214.0 & 36.8 & 8339 & 10424 & 44.4 \\
\hline T7: $\mathrm{N}$ application at LCC threshold $\leq 5.5$ & 32.4 & 209.6 & 36.6 & 7799 & 9827 & 44.2 \\
\hline T8: $\mathrm{N}$ application at LCC threshold $\leq 6$ & 30.4 & 197.0 & 33.7 & 7504 & 9455 & 44.2 \\
\hline T9: Recommended nitrogen $\left(190 \mathrm{~kg} \mathrm{ha}^{-1}\right)$ & 31.8 & 206.0 & 35.9 & 7756 & 9696 & 44.4 \\
\hline T10: Absolute control & 14.2 & 160.0 & 23.0 & 3725 & 5264 & 41.4 \\
\hline S.Em.土 & 0.9 & 5.6 & 1.0 & 227 & 314 & $\mathbf{0 . 0}$ \\
\hline C.D. $(\mathrm{P}=0.05)$ & 2.6 & 16.6 & 3.0 & 674 & 934 & NS \\
\hline
\end{tabular}

LCC: Leaf Colour Chart NS: Non significant

Table.3 Cost of cultivation, gross returns, net returns and B: C ratio of maize production as influenced by $\mathrm{N}$ application based on leaf colour chart thresholds under irrigated condition

\begin{tabular}{|c|c|c|c|c|}
\hline Treatments & Cost of cultivation (Rs. ha ${ }^{-1}$ ) & Gross returns (Rs. ha-1) & Net returns (Rs.ha $\left.{ }^{-1}\right)$ & B:C ratio \\
\hline T1: $\mathrm{N}$ application at LCC threshold $\leq 1$ & 38921 & 76551 & 37630 & 1.97 \\
\hline T2: $\mathrm{N}$ application at LCC threshold $\leq 2$ & 39221 & 90594 & 51374 & 2.31 \\
\hline T3: $\mathrm{N}$ application at LCC threshold $\leq 3$ & 39281 & 94535 & 55255 & 2.41 \\
\hline T4: $\mathrm{N}$ application at LCC threshold $\leq 4$ & 39551 & 108101 & 68550 & 2.73 \\
\hline T5: $\mathrm{N}$ application at LCC threshold $\leq 4.5$ & 40642 & 110486 & 69844 & 2.72 \\
\hline T6: $\mathrm{N}$ application at LCC threshold $\leq 5$ & 42975 & 123624 & 80650 & 2.88 \\
\hline T7: $\mathrm{N}$ application at LCC threshold $\leq 5.5$ & 43826 & 115664 & 71838 & 2.64 \\
\hline T8: $\mathrm{N}$ application at LCC threshold $\leq 6$ & 44797 & 111284 & 66487 & 2.48 \\
\hline T9: Recommended nitrogen $\left(190 \mathrm{~kg} \mathrm{ha}^{-1}\right)$ & 43290 & 114988 & 71697 & 2.66 \\
\hline T10: Absolute control & 32410 & 55532 & 23122 & 1.71 \\
\hline S.Em. \pm & & & 3373 & 0.09 \\
\hline C.D. $(\mathrm{P}=0.05)$ & & & 10022 & 0.25 \\
\hline
\end{tabular}

LCC: Leaf Colour Chart 
Fig.1 Regression and correlations between grain yield $\left(\mathrm{kg} \mathrm{ha}^{-1}\right)$ and $\mathrm{N}$ applied rate $\left(\mathrm{kg} \mathrm{ha}^{-1}\right)$ as influenced by $\mathrm{N}$ management through leaf colour chart thresholds in maize under irrigated condition

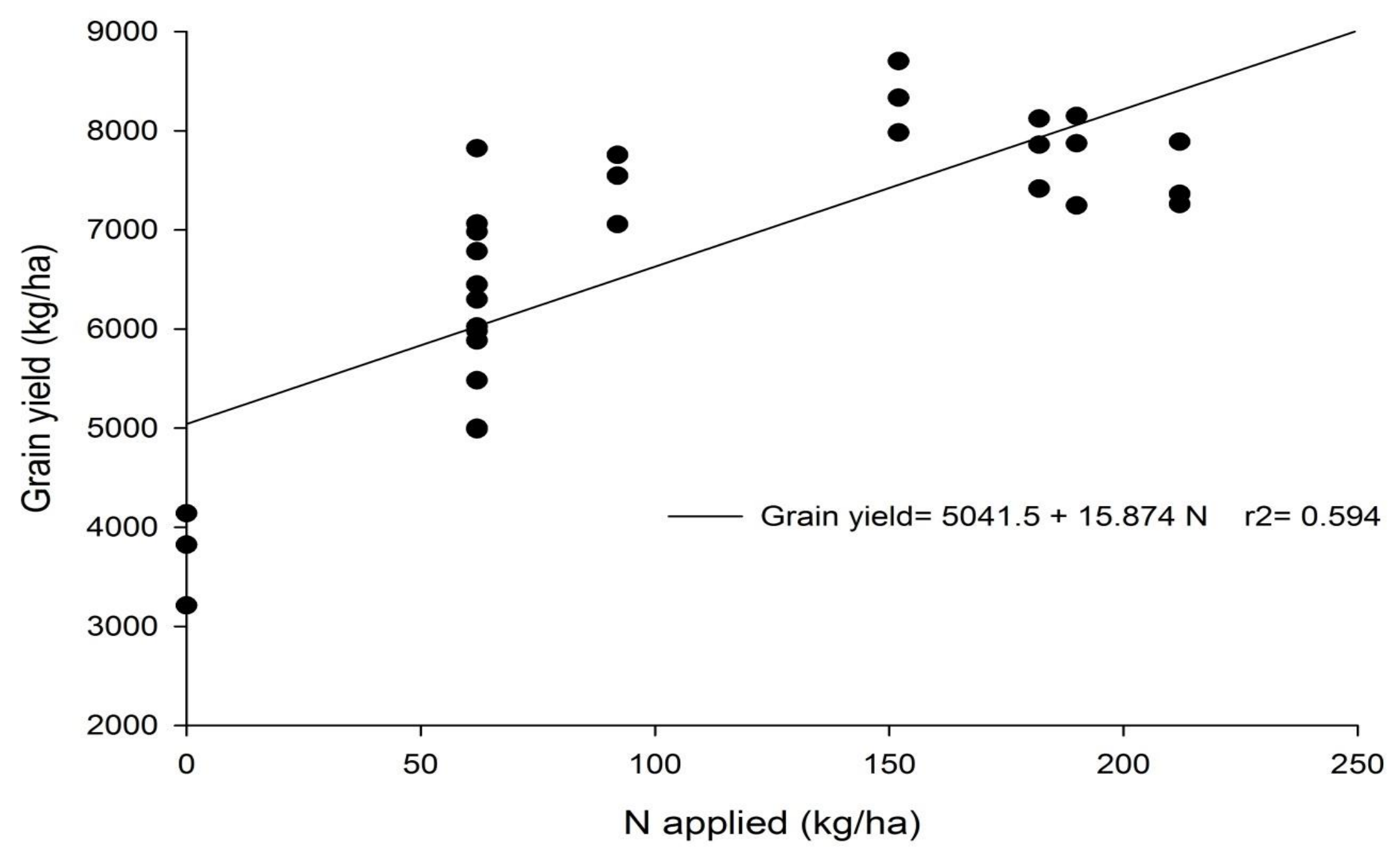


The higher grain and stover yield obtained when $\mathrm{N}$ was managed at LCC threshold $\leq 5$ was obviously due to favourable nutrition or balanced level of nutrient application during the crop growth stages. However, in LCC-1, 2,3 , and 4 the amount of $\mathrm{N}$ was less and plant suffer for want of $\mathrm{N}$ at critical stages of crop growth $\left(4^{\text {th }}\right.$ leaf, $8^{\text {th }}$ leaf stage, tasseling and silking) where $\mathrm{N}$ is most required at these stages as we seen from the uptake of $\mathrm{N}$. This was further evidenced by positive relationship between $\mathrm{N}$ applied and grain yield $\left(\mathrm{r}^{2}=0.59\right)$ (Fig. 1). Similarly, these results are in accordance with findings of Roland et al., (2013) they reported that, LCC threshold 5 recorded substantially better grain $\left(44 \mathrm{q} \mathrm{ha}^{-1}\right)$ and straw yield $\left(70 \mathrm{ha}^{-1}\right)$ of maize in comparison to LCC threshold at 4 and 3 . Significantly higher growth and yield additives had been located with LCC $<5$. These results were also in conformity with findings of Angadi et al., (2002); Datturam and Shashidhar (2012); Sarnaik (2010); Mallikarjuna et al., (2016) and Singh et al., (2016). Harvest index indicates the percentage of dry matter partitioned and accumulated in the economic portion. In the present investigation higher harvest index (44.4\%) was registered with $\mathrm{N}$ application at LCC threshold $\leq 5$ as compared to other treatments (Table 2). Similar results were reported by Jayanthi et al., (2007) where in the harvest index favourably increased with increasing $\mathrm{N}$ rates in LCC based nitrogen application.

The increased yield under $\mathrm{N}$ application at LCC threshold $\leq 5$ resulted in improvement of economic returns of maize production. The higher gross returns and net returns was registered with $\mathrm{N}$ application at LCC threshold $\leq 5$ (Rs. 1,23,624 $\mathrm{ha}^{-1}$ and Rs. $80,650 \mathrm{ha}^{-1}$, respectively) compared to rest of the treatments and it was followed by $\mathrm{N}$ application at LCC threshold $\leq 5.5$ and recommended nitrogen. Relatively lower gross returns and net returns were recorded in absolute control (Rs. 55,532 $\mathrm{ha}^{-1}$ and 23,122 $\mathrm{ha}^{-1}$, respectively) (Table 3 ). These higher gross and net returns were mainly attributed to higher grain and straw yield. The results are in line with the earlier findings of Sarnaik (2010) reported that higher gross returns (Rs. 74,795 $\mathrm{ha}^{-1}$ ) and net returns (Rs. 58,257 $\mathrm{ha}^{-1}$ ) was noticed with LCC-5 $+30 \mathrm{~kg} \mathrm{~N} \mathrm{ha}{ }^{-1}$ dressing $^{-1}$ over all different remedy mixtures admitting controls in maize. These results were also in conformity with findings of Chandrasekhara (2009), Datturam and Shashidhar (2012) and Mathukia et al., (2014).

Significantly higher benefit cost ratio (2.88) was recorded with $\mathrm{N}$ application at LCC threshold $\leq 5$ compared to rest of the treatments and it was statistically on par withN application at LCC threshold $\leq 4$ (2.73), $\mathrm{N}$ application at LCC threshold $\leq 4.5$ (2.72), recommended nitrogen (2.66) and $\mathrm{N}$ application at LCC threshold $\leq 5.5$ (2.64) (Table 3). Similar results were also reported by Maiti and Das (2006), Ravi et al., (2007).

Thus, the study revealed that presently farmers are applying lower fertilizer than crop requirement and by application of $\mathrm{N}$ fertilizers based on leaf colour chart at threshold $\leq 5$ was optimum to achieve higher yield, net returns, and increase the efficiency of applied fertilizers with a saving of $40 \mathrm{~kg} \mathrm{~N}$ $\mathrm{ha}^{-1}$ over recommended $\mathrm{N}$ for the region. Thus, LCC helps to economize $\mathrm{N}$ use besides reducing cost of maize production.

\section{References}

Angadi, V.V., S. Rajakumara, Ganajaxi., A.Y. Hugar, B. Basavaraj, S.V. Subbaiah, V. Balasubramanian, 2002. Determining the leaf colour chart threshold value for nitrogen management in rainfed rice. International Rice Research Institute Notes. 27(2): 34-35.

Balasubramanian, P., 1984. Nitrogen fertilization for short duration rice. International Rice 
Research Institute Notes., 9: 29.

Balasubramanian, V., A.C. Morales, R.T. Cruz, and S. Abdulrachman, 1999. On farm adaptation of knowledge intensive nitrogen management technologies for rice systems. Nutrient Cycling in Agro-Ecosystems., 53: 5969.

Balasubramanian, V., A.C. Morales, R.T. Cruz, T.M. Thiyagarajan, R. Nagarajan, M. Babu, S. Abdulrachman, and L.H. Hai, 2000. Application of the chlorophyll meter (SPAD) technology for real-time $\mathrm{N}$ management in rice. A review, International Rice Research Institute Notes., 251:4-8.

Balasubramanian, V., A.C. Morales, R. Torres, G. Gines, W. Collado, and E. Redona, 2002. Response of rice hybrid and an inbred variety to urea briquette deep placement in the Philippines. Journal of Agricultural Research Manage. 1: 50-60.

Chandrashekara, C.P. 2009. Resource management in sugarcane (Saccharum officinarum L.) through drip irrigation, fertigation, planting pattern, and LCC based N application and area - production estimation through remote sensing. Ph.D Thesis, University of Agricultural Sciences, Dharwad (India).

Datturam, K. and G.B. Shashidhar, 2012. Needbased nitrogen management using leaf colour chart in sweet corn genotypes (Zea mays L. Saccharata). Karnataka Journal of Agricultural Sciences., 25(4): 557-608.

Furuya, S., 1987. Growth diagnosis of rice plants by means of leaf color. Japan Agricultural Research., 20, 147-153.

Jayanthi, T., S.K. Gali, V.V. Angadi, and V.P. Chimmad, 2007. Effect of leaf colour chart based nitrogen management on growth and yield parameters of rainfed rice. Karnataka Journal of Agricultural Sciences., 20(2): 272275.
Maiti, D. and D.K. Das, 2006. Management of nitrogen through the use of leaf colour chart (LCC) and soil plant analysis development (SPAD) in wheat under irrigated ecosystem. Archives of Agronomy and Soil Science., 52(1): 105-112.

Mallikarjuna Swamy, M.R. Umesh, N. Ananda, U.K. Shanwad, A. Amaregouda, and N. Manjunath, 2016. Precision nitrogen management for rabi sweet corn (Zea mays saccharata $\mathrm{L}$.) through decision support tools. Journal of Farm Science., 29(1):14-18.

Mathukia, R. K., R. Puja, and N.M. Dadhania, 2014, climate change adaptation: real time nitrogen management in maize (Zea mays L.) using leaf colour chart. Current World Environment., 9(3):1028-1033.

Ravi, S., B. Chandrasekaran, and S. Ramesh, 2007. Exploitation of hybrid vigour in rice hybrid (Oryza sativa L.) through green manure and leaf colour chart (LCC) based $\mathrm{N}$ application. Asian Journal of Plant Science., 6(2): 282-287.

Roland, J. B., C.Rowena, D.B. Marcovan, and G. Gabinete, 2013. Nutrient management decision tool for small-scale rice and maize farmers. Computers and Electronics in Agriculture., 12: 22-28.

Sarnaik, P., 2010. Nitrogen management in hybrid maize through leaf colour chart, M. Sc (Agri.) Thesis, University of Agricultural Sciences, Dharwad.

Singh, V., B. Amit, and P.S. Ajeet, 2016. Evaluation of leaf-colour chart for need-based nitrogen management in maize (Zea mays L.) grown under irrigated condition of Mollisols. Indian Journal of Agronomy, 61 (1): 47-52.

Witt, C., J.M., Pasuquin, R. Mutters, and R.J. Buresh. 2005. New leaf colour chart for effective nitrogen management in rice. Better Crops, 89(1): 36-39.

\section{How to cite this article:}

Shivakumar, M.A. Basavanneppa, B.G. Koppalkar, M.R. Umesh and Ashok Kumar Gaddi. 2017. Calibrating the Leaf Colour Chart for Nitrogen Management in Maize (Zea mays L.) under Irrigated Condition. Int.J.Curr.Microbiol.App.Sci. 6(11): 1030-1036.

doi: https://doi.org/10.20546/ijcmas.2017.611.120 